\title{
Nickel chloride administration prevents the growth of oral squamous cell carcinoma
}

\author{
Hirotaka Ota $^{1,2, *}$, Takashi Shionome ${ }^{3, *}$, Hisashi Suguro ${ }^{4,5}$, Satsuki Saito ${ }^{6}$, Kosuke \\ Ueki $^{6}$, Yoshinori Arai ${ }^{7}$ and Masatake Asano ${ }^{1,2}$ \\ ${ }^{1}$ Department of Pathology, Nihon University School of Dentistry, Tokyo, Japan \\ ${ }^{2}$ Division of Immunology and Pathobiology, Nihon University School of Dentistry, Tokyo, Japan \\ ${ }^{3}$ Department of Partial Denture Prosthodontics, Nihon University School of Dentistry, Tokyo, Japan \\ ${ }^{4}$ Department of Endodontics, Nihon University School of Dentistry, Tokyo, Japan \\ ${ }^{5}$ Division of Advanced Dental Treatment, Dental Research Center, Nihon University School of Dentistry, Tokyo, Japan \\ ${ }^{6}$ Division of Applied Oral Sciences, Nihon University Graduate School of Dentistry, Tokyo, Japan \\ ${ }^{7}$ Nihon University School of Dentistry, Tokyo, Japan \\ *These authors contributed equally to this work \\ Correspondence to: Masatake Asano, email: asano.masatake@nihon-u.ac.jp \\ Keywords: nickel chloride; oral squamous cell carcinoma; matrix metalloproteinase; nude mouse; nuclear factor-kappa B \\ Received: April 27, $2017 \quad$ Accepted: September 03, $2017 \quad$ Published: May 08, 2018
}

Copyright: Ota et al. This is an open-access article distributed under the terms of the Creative Commons Attribution License 3.0 (CC BY 3.0), which permits unrestricted use, distribution, and reproduction in any medium, provided the original author and source are credited.

\section{ABSTRACT}

The effect of $\mathrm{NiCl}_{2}$ on oral squamous cell carcinoma-derived cell line $\mathrm{HSC} 3$ was examined. Incubation with $1 \mathrm{mM} \mathrm{NiCl}$ significantly reduced the expression of MMPs at mRNA and protein levels. The in vivo orthotopic implantation model was established by injecting highly metastatic subcell line HSC3-M3 to nude mouse tongue. After 1 week of injection, mice were fed with or without $1 \mathrm{mM}$ $\mathrm{NiCl}_{2}$-containing water for two to three weeks. Immunohistochamical examination revealed that MMP9 expression was drastically reduced in $\mathrm{NiCl2}$-fed mice. By CT images, cancer mass was observed as a translucent area in control mice. In $\mathbf{~ N i C l}_{2}-$ fed mice, much highly translucent area was observed within the translucent area. Histologically, this area corresponded to the necrotic area in the tumor mass. Realtime PCR analysis revealed the reduced expression of angiogenic factors such as IL-8 and VEGF mRNA in $\mathrm{NiCl}_{2}$-fed mice. To further examine the effect of $\mathrm{NiCl}_{2}$ on metastasis, human $\beta$-globin gene expression in regional lymphnodes was compared. The $\beta$-globin gene was totaly absent in $\mathrm{NiCl}_{2}$-fed mice. Moreover, various cancer metastasis-related genes were inhibited in $\mathrm{NiCl}_{2}$-fed mice by PCR array analysis. The results indicated that $\mathrm{NiCl}_{2}$ might be a promising new anti-cancer therapeutics for the oral cancer treatment.

\section{INTRODUCTION}

Oral squamous cell carcinoma (OSCC) is the most frequently occurring malignant tumor in the oral cavity [1]. Aberrant activities of transcription factors in OSCC result in the augmented expression of several other factors that contribute to tumor progression [1]. NF- $\mathrm{kB}$, one of the most studied and important transcription factors belongs to a family of five members: p50 (NFKB1), p52 (NFKB2), p65 (RELA), c-Rel (REL), and RelB (RELB) [2]. Upon activation, these factors translocate to the nucleus where they participate in the expression of the genes involved in inflammatory and immune responses, as well as in cell proliferation and survival [3]. NF- $\mathrm{KB}$ protein levels increase gradually from premalignant lesions to invasive cancer, indicating its role during the early stages of carcinogenesis [4-7]. In a previous study, we reported the inhibitory effect of $\mathrm{Ni}^{2+}$ ions on NF- $\mathrm{kB}$ activity wherein, the ions directly bind to NF- $\mathrm{KB}$ p50 subunit and inhibit its nuclear transport, thereby, inhibiting IL-8 secretion [8]. 
Matrix metalloproteinases (MMPs) are the most important players in extracellular matrix remodeling and more than 20 members of the MMP family have been characterized to date $[9,10]$. MMPs belong to the zincdependent family of endopeptidases which are implicated in a variety of physiological processes $[9,10]$. One of the most relevant functions of the MMPs is the degradation of physical barriers, such as basement membrane [11-13]. As the invasive potential of various cancers depends on the ability of tumor cells to degrade the basement membrane [14], MMPs have been targeted by several therapeutic agents [11]. MMP2 and MMP9, in particular, have the ability to cleave type IV collagen, the main component of the basement membrane, and contribute to the metastasis of tumor cells [11-13].

The expression of MMPs in OSCC has been studied extensively $[5,15]$. MMP expression is partially dependent on NF-kB [16]; hence, we speculated that $\mathrm{Ni}^{2+}$ ions might be able to inhibit the expression of these proteinases in OSCC. The aim of the present study was to examine whether $\mathrm{Ni}^{2+}$ ions can inhibit MMP expression and thereby inhibit growth and metastasis in OSCC. Our findings suggest that $\mathrm{Ni}^{2+}$ ions may be considered as a novel candidate for cancer treatment.

\section{RESULTS}

\section{$\mathrm{Ni}^{2+}$ inhibits MMP expression}

We first attempted to examine the influence of $\mathrm{Ni}^{2+}$ ions on the expression of MMPs. For this purpose, HSC3 was cultured in the presence or absence of $1 \mathrm{mM}$ $\mathrm{NiCl}_{2}$ for $24 \mathrm{~h}$ and MMP expression was examined by real-time PCR. MMP1, 2, 9, 13 and 14 were expressed in the HSC3 cells (Figure 1A). The expression level of each MMP without $\mathrm{Ni}^{2+}$ ions was set as 1 and the relative expression levels were compared in the cells stimulated with $\mathrm{Ni}^{2+}$ ions (Figure $1 \mathrm{~A}$ ). $\mathrm{Ni}^{2+}$ ions reduced the expression of all the MMPs in OSCC. The inhibition was most prominent for MMP9 and MMP14, with nearly $80 \%$ reduction when compared to the non-stimulated cells. On the other hand, a $35 \%-50 \%$ reduction was observed in MMP1, 2 and 13 levels. To confirm the results obtained above, we performed the same experiments using other cancer cell lines such as human skin-derived squamous cell carcinoma HSC1 and HSC5 and human OSCC HSC2. As shown in Figure 1A, MMP9 expression was drastically reduced in all cell lines by $\mathrm{Ni}^{2+}$ ions. MMP9 is known to play an intrinsic role in the invasive growth of cancer cells; therefore, the following experiments were performed with this particular peptidase. In order to examine the mechanisms involved in $\mathrm{Ni}^{2+}$ ions-mediated MMP9 reduction at the protein level, IP followed by Western blotting was performed. HSC3 was cultured with or without $\mathrm{Ni}^{2+}$ ions and the cell lysates were prepared.
As shown in Figure 1B, a clear MMP9 band was detected when the cells were cultured without $\mathrm{Ni}^{2+}$ ions. In contrast, $\mathrm{Ni}^{2+}$ ions-treatment significantly reduced the intensity of the MMP9 band (Figure 1B).

\section{$\mathrm{Ni}^{2+}$ ions reduce MMP9 expression through NF-KB inhibition}

In a previous study, $\mathrm{Ni}^{2+}$ ions were demonstrated to inhibit NF- $\kappa \mathrm{B}$ activity [8]. To examine the contribution of NF- $\mathrm{KB}$ on $\mathrm{Ni}^{2+}$ ions-mediated MMP9 inhibition, we cloned the 5'-UTR of the MMP9 gene and performed a luciferase assay. The structure of the 5'-UTR is illustrated in Figure 2. We first transfected the wild type (pGL4MMP9-wt) construct to HSC3 after which, the cells were stimulated with or without $\mathrm{Ni}^{2+}$ ions for 12 or $24 \mathrm{~h}$. Luciferase activity of the cells without $\mathrm{Ni}^{2+}$ ions, after $12 \mathrm{~h}$ of culture, was set as 1 and compared with the $\mathrm{Ni}^{2+}$ ions-stimulated samples. Luciferase activity was slightly reduced at $12 \mathrm{~h}$ of stimulation $(\sim 0.75)$; however, after $24 \mathrm{~h}$ stimulation, the activity was increased to 1.87 in the absence of $\mathrm{Ni}^{2+}$ ions and reduced to 0.73 in the presence of $\mathrm{Ni}^{2+}$ ions (Figure 2B). Based on the presumption that the reduced luciferase activity might be attributed to the inactivation of NF- $\mathrm{kB}$ by $\mathrm{Ni}^{2+}$ ions, we constructed NF- $\mathrm{\kappa B}-$ deletion mutants lacking upper and lower NF- $\mathrm{kB}$ binding sites (Figure 2A). MMP9 5'-UTR encompasses two NF$\kappa \mathrm{B}$ binding sites. Each site was deleted and designated as $\Delta$ upper and $\Delta$ lower, respectively. In each case, luciferase activity in cells without $\mathrm{Ni}^{2+}$ ions stimulation was set as 1. The luciferase activity was reduced to 0.48 and 0.69 in the $\Delta$ upper and $\Delta$ lower mutants, respectively, in the cells stimulated with $\mathrm{Ni}^{2+}$ ions (Figure 2C). The results indicate that both upper and lower NF-kB-binding sites contribute to $\mathrm{Ni}^{2+}$ ions-mediated MMP9 reduction with a slight predominance of the upper region.

\section{$\mathrm{Ni}^{2+}$ ions in drinking water inhibits MMP9 expression}

To examine whether MMP9 expression is inhibited in vivo, cancer mass formation was induced by injecting HSC 3 cells into the tongues of nude mice. Subsequently, the mice were fed with $1 \mathrm{mM} \mathrm{NiCl}_{2}$-containing water or regular water. The tumor mass size was measured at this time point and not significant difference between the two groups (regular water-fed group: $6.64 \pm 0.63 \mathrm{~mm}^{3}$, $\mathrm{NiCl}_{2}$-fed group: $6.07 \pm 1.02 \mathrm{~mm}^{3}$ ) were observed. The tumor tissue was excised and subjected to anti-MMP9 staining. As shown in Figure 3A (left column), tumor cells showed dense staining for MMP9 in mice that were fed normal water; in contrast, significantly reduced intensity was observed in tumor cells derived from the mice fed with $\mathrm{NiCl}_{2}$-containing water (Figure 3A, right column). The reduction of MMP9 expression was 
confirmed by immunoprecipitation followed by western blotting (Figure 3B). Significant MMP9 reduction was observed in mice fed with $\mathrm{NiCl}_{2}$-containing water. These results indicated that $\mathrm{Ni}^{2+}$ ions can reduce MMP9 expression in vivo.

\section{Cancer growth inhibition}

Growth and invasive potential of tumor cells is dependent on the spontaneous activity of transcription

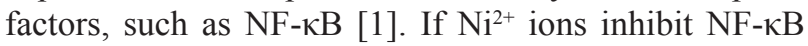

A

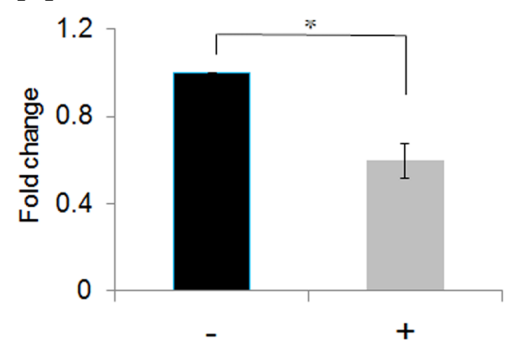

MMP2
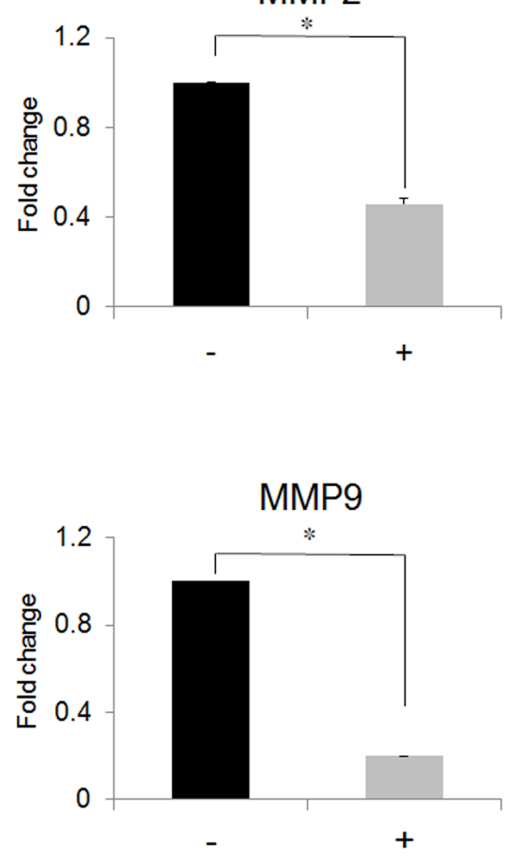

B

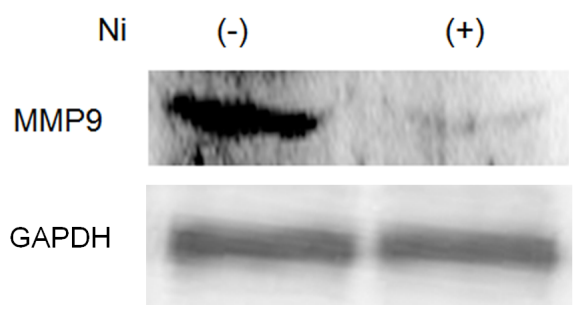

MMP13

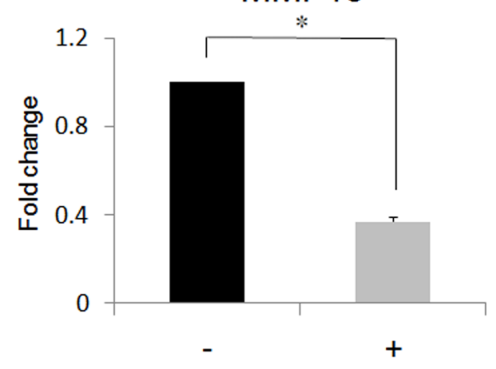

MMP14
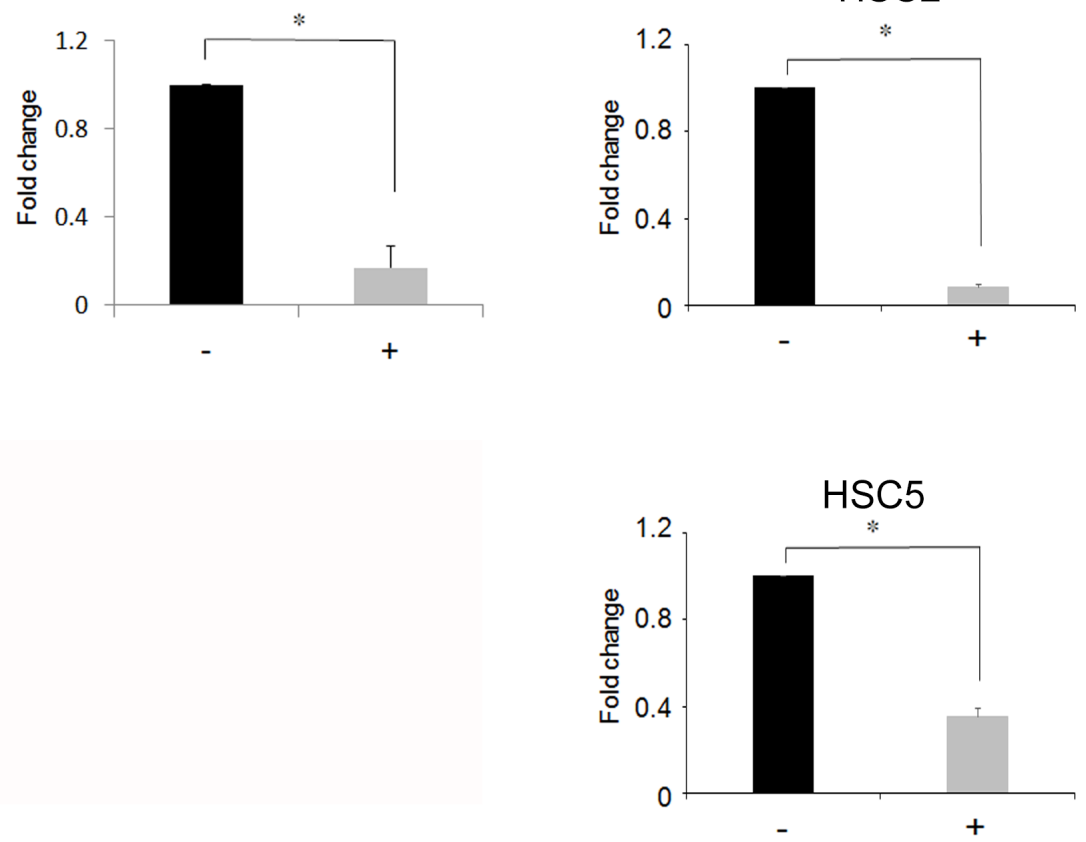
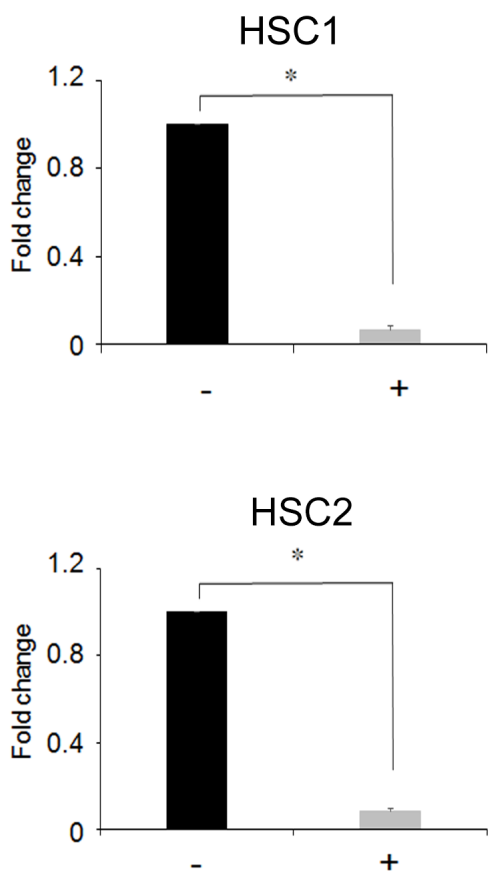

Figure 1: Inhibition of MMP expression following $\mathbf{N i}^{2+}$-treatment. (A) HSC3 cells and other squamous cell carcinoma cell lines (HSC1, 2 and 5) were cultured with or without $\mathrm{NiCl}_{2}(1 \mathrm{mM})$ for $24 \mathrm{~h}$. The total RNA was purified and subjected to real-time PCR. MMPs expression in the cells cultured without $\mathrm{Ni}^{2+}$ was set as 1 . The mean \pm standard deviation (SD) of three separate experiments are shown. $\left({ }^{*} p<0.05\right)$. (B) HSC3 cells were cultured with or without $1 \mathrm{mM} \mathrm{Ni}^{2+}$ for $24 \mathrm{~h}$. At the end of culture, the cell lysates were harvested and subjected to immunoprecipitation using anti-MMP9Ab (upper panel) or anti-GAPDH Ab (lower panel), followed by protein G-sepharose. The samples were separated with 10\% SDS-PAGE and further subjected to Western blotting. Mouse anti-human MMP9 Ab or mouse antihuman GAPDH Ab followed by HRP-labelled goat anti-mouse $\operatorname{IgG}(\mathrm{H}+\mathrm{L}) \mathrm{Ab}$ were used. The data is representative of three independent experiments. 
activity, $\mathrm{Ni}^{2+}$ ions might be applied as anti-cancer reagent. To examine this possibility, HSC3-M3 cells $\left(5 \times 10^{5}\right)$, the highly metastatic subclone of HSC3, was injected in nude mice tongue. A contrast agent was injected and CT images of the primary regions were obtained. As shown in Figure 4A (frontal section), the cancer occupied the entire region of the tongue and presented as a radiolucent area with relatively clear borders in the regular water-fed group. The area was uniform in translucency and showed the so-called ball-in-hands image (Figure 4A, left panel). On the other hand, in the $\mathrm{Ni}^{2+}$ ions-fed group, a hyperradiolucent area was observed within the radiolucent

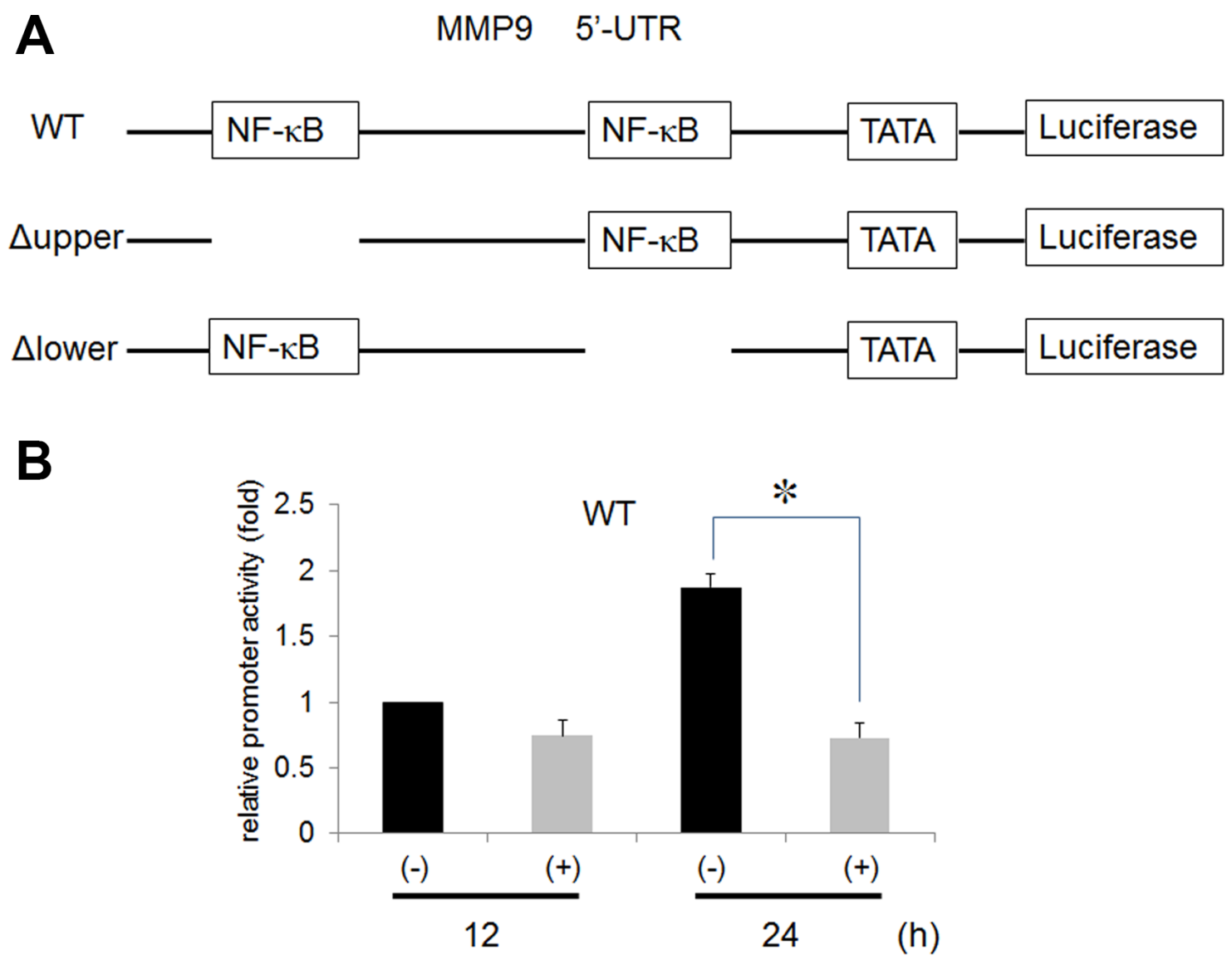

C

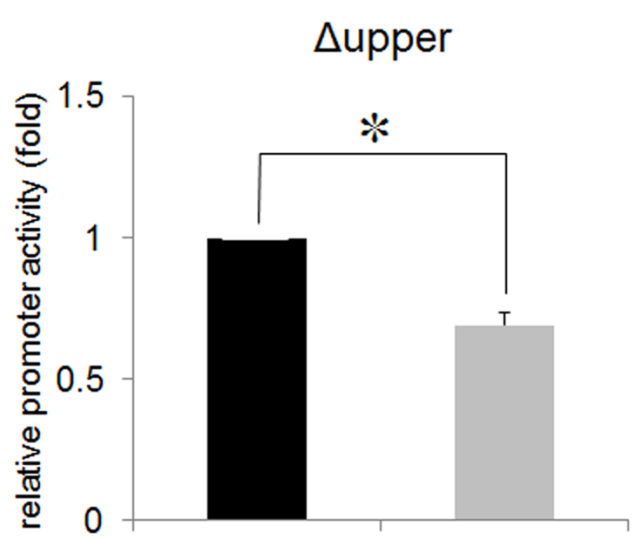

$(-)$

(+)

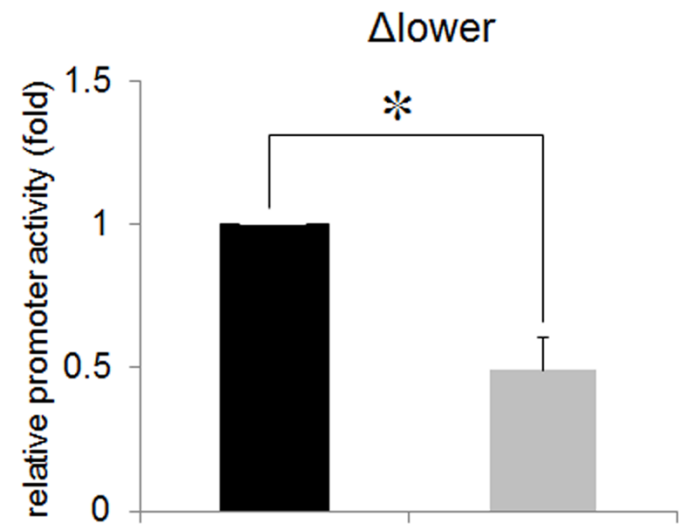

$(-)$

$(+)$

Figure 2: $\mathbf{N i}^{2+}$ inhibited the NF-KB activity. (A) Wild type $5^{\prime}$-UTR of the MMP9 gene was fused to luciferase reporter construct (WT). The upper ( $\Delta$ upper) and lower ( $\Delta$ lower) NF- $\mathrm{kB}$ binding sites were deleted by site-directed mutagenesis. (B) HSC3 cells were transfected with WT or $(\mathbf{C}) \Delta$ upper or $\Delta$ lower along with $\mathrm{pRL} / \mathrm{CMV}$ vector for $5 \mathrm{~h}$. The cells were further cultured for $18 \mathrm{~h}$ and stimulated with or without $1 \mathrm{mM} \mathrm{Ni}^{2+}$ for $12 \mathrm{~h}$ or $24 \mathrm{~h}$. At the end of stimulation, the cells were lysed with passive lysis buffer and luciferase activity was measured. The mean $\pm \mathrm{SD}$ of three independent experiments was shown. $\left({ }^{*} p<0.05\right)$. 
area (Figure 4A, right panel). The primary region was further examined histologically by HE staining. Solid cancer nests were noted in the regular water-fed group, (Figure 4B, left panel). In contrast, in the $\mathrm{Ni}^{2+}$ ions-fed group, necrotic areas were observed within the cancer nests (Figure 4B, right panel); this may be attributed to a reduction in angiogenic activity in the $\mathrm{Ni}^{2+}$ ions-fed group. Based on this assumption, we compared the expression of the angiogenic factors IL-8 and VEGF between the $\mathrm{Ni}^{2+}$ ions-fed and non-fed groups of mice. Tumor mass was excised and subjected to real-time PCR for IL-8 and VEGF expression. In the $\mathrm{Ni}^{2+}$ ions-fed group, significant reductions in both genes $(\sim 100$-fold and $\sim 1.5$-fold for IL-8 and VEGF, respectively) were observed (Figure 4C).

\section{Anti-metastatic effect of $\mathrm{Ni}^{2+}$ ions}

In order to examine the anti-metastatic effect of $\mathrm{Ni}^{2+}$ ions, regional lymph nodes were obtained from the mice and subjected to nested-PCR for $\beta$-globin gene detection. As HSC3-M3 cells are of human origin, detection of the human $\beta$-globin gene indicates the establishment of metastasis. Similar amounts of $\beta$-globin gene were detected in the primary tongue regions in both groups (Figure 5A, upper panel). On the other hand, a drastic reduction in $\beta$-globin gene expression was noted in the $\mathrm{Ni}^{2+}$ ions-fed group (Figure 5A, lower panel) when compared with the $\mathrm{Ni}^{2+}$ ions-unfed control group (Figure 5A).

\section{PCR array analysis}

The influence of $\mathrm{Ni}^{2+}$ ions on the expression of cancer metastatic genes was further examined. RNA was purified from the cancer mass obtained from the $\mathrm{Ni}^{2+}$ ions-fed and -unfed mice, and subjected to PCR array analysis. The list of the genes analysed were shown in Table 1. Consistent with the data shown in Figure 1, MMP2, 3, 7, 9, 11 and 13 expressions were drastically reduced in the $\mathrm{Ni}^{2+}$ ions-fed group (Figure 5B). Except for the significant increase in elastase and Eph receptor B2 (epht2) expression (Figure 5B), most of the metastasisrelated genes were reduced in the $\mathrm{Ni}^{2+}$ ions-fed group (Figure 5B).

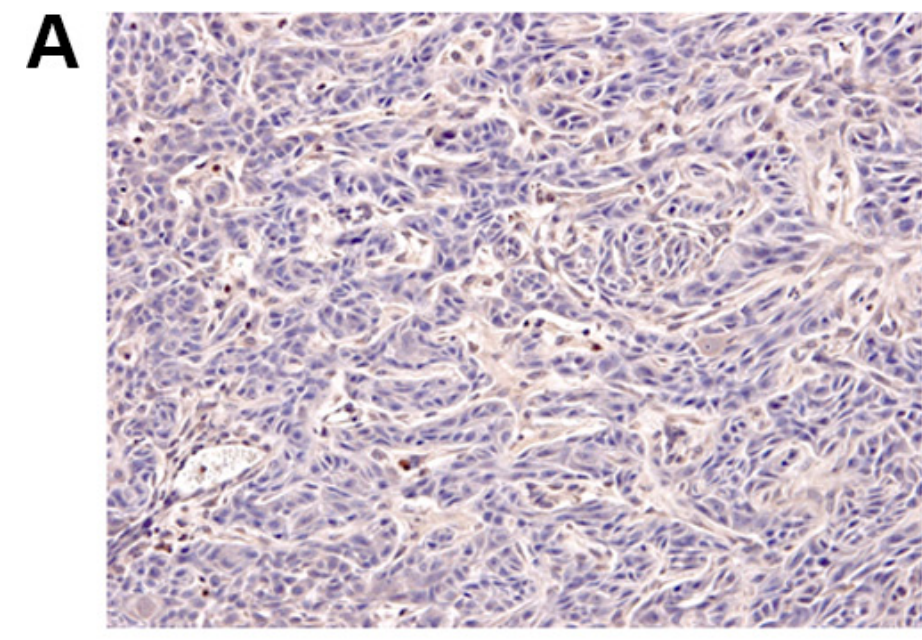

$(-)$

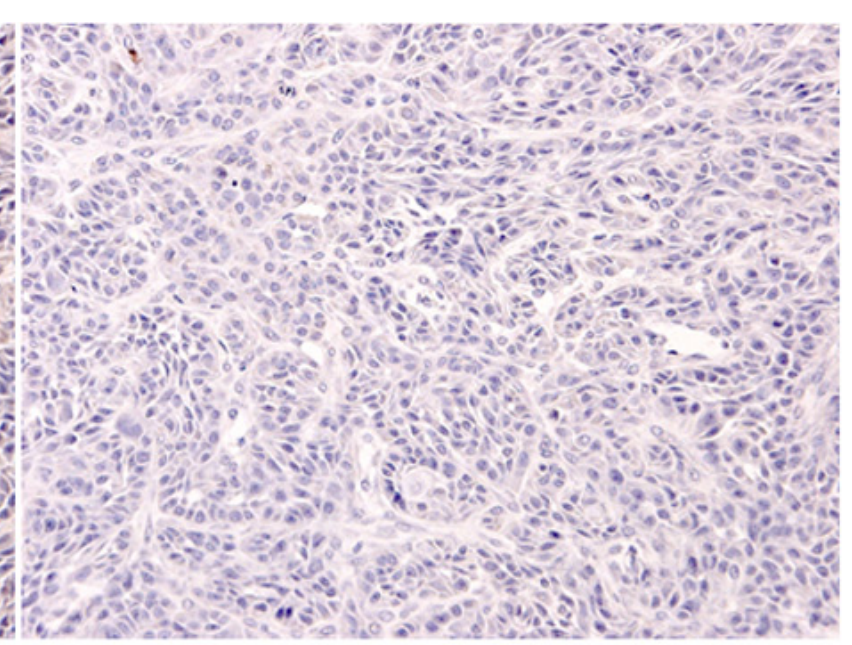

$(+)$

B

$(-)$

$(+)$

Figure 3: Addition of $1 \mathbf{m M ~ N i C l}$ in drinking water inhibited MMP9 expression. HSC3 cells were xenografted to the tongue of nude mice. After tumor mass formation, mice were fed with regular drinking water $(n=5)$ or $1 \mathrm{mM} \mathrm{NiCl}_{2}$-containing water $(n=7)$ for 1 week. (A) The tissue was excised, formalin-fixed and embedded in paraffin. The expression of MMP9 was examined by immunohistochemical staining using anti-MMP9 Ab as the first Ab. (B) The excised tissue were minced, lysed with cell lysis buffer and subjected to IP-Western. Representatives of three independent experiments were shown for both (A and B). 


\section{DISCUSSION}

For effective tumor growth and invasion, the surrounding stroma must be degraded by the cancer cells [17]. One of the most important players involved in this process are the MMPs. MMP gene expression is partly regulated by $\mathrm{NF}-\kappa \mathrm{B}[18]$. $\mathrm{As} \mathrm{Ni}^{2+}$ ions were shown to inactivate NF- $\kappa \mathrm{B}$ in our previous study [8], herein, we first examined the effect of $\mathrm{Ni}^{2+}$ ions on MMP expression. Expression of MMP1, 2, 9, 13 and 14 in OSCCs was
A

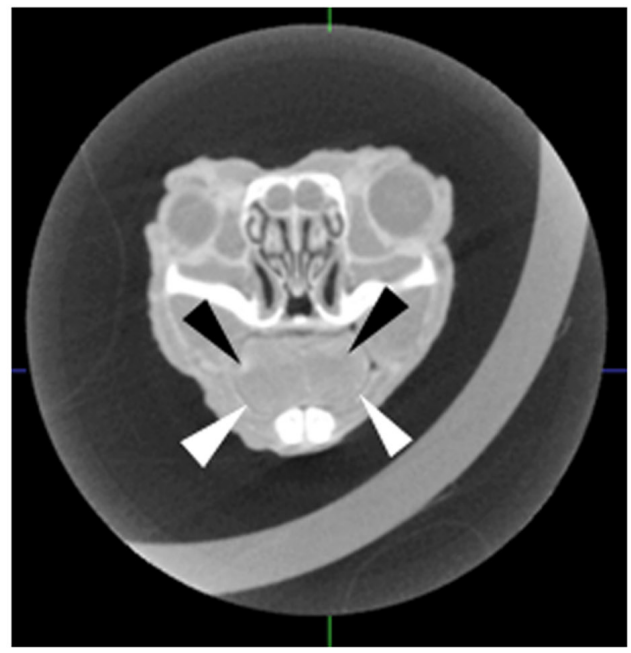

B

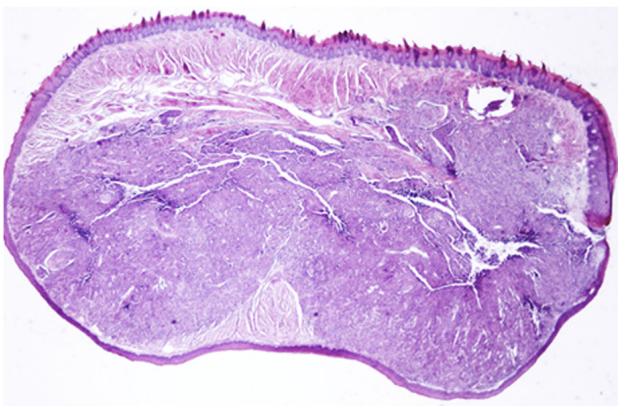

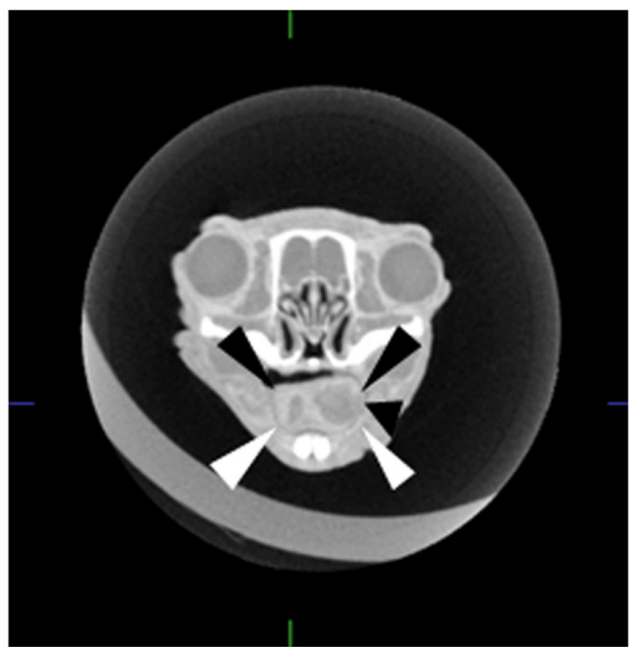

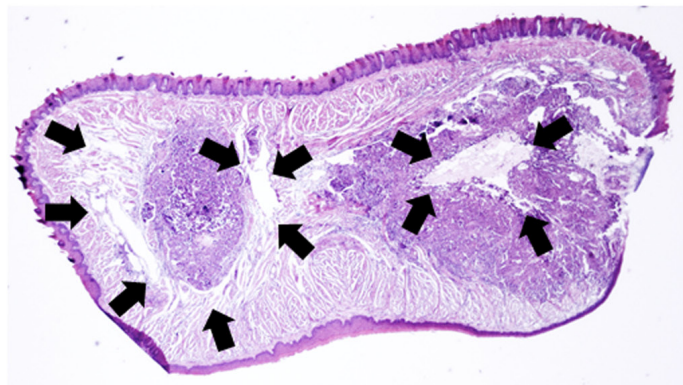

C

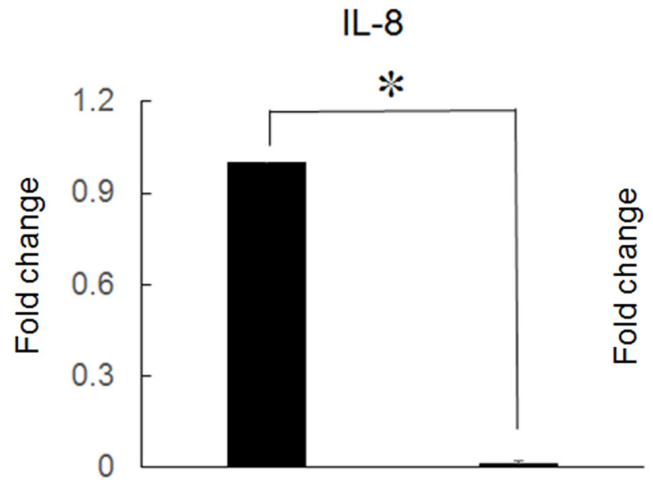

$(-)$

$(+)$

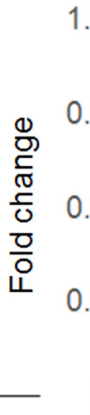

0

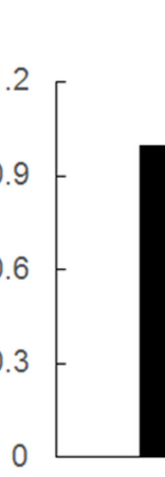

VEGF

Figure 4: Production of hyper-lucent areas within the cancer mass. (A) HSC3-M3 cells $\left(5 \times 10^{5} / 30 \mu \mathrm{l}\right)$ were injected into nude mice tongue. After cancer mass formation (1 week), mice were fed with $(n=5)$ or without $1 \mathrm{mM} \mathrm{NiCl}_{2}$-containing water $(n=7)$ for 2 weeks. A contrast agent was injected into the tail vein and CT images of the primary regions were obtained. Left panel: regular water, arrowheads indicate the translucent area. Right panel: $\mathrm{NiCl}_{2}$, The hyper translucent area can be observed in the translucent area. The representative of 5 (non-fed) and 7 (Ni2+-fed) different images was shown. (B) The primary region was excised, fixed and embedded in paraffin. The specimens were stained by H\&E staining. Left panel: regular water. Right panel: $\mathrm{NiCl}_{2}$-containing water. The arrows indicate the necrotic area. Representative data of at least five different experiments for each group are shown. (C) RNA was extracted from the tongue tissues and subjected to real-time PCR to examine IL-8 and VEGF expression. The mean \pm SD of three separate experiments are shown. $\left({ }^{*} p<0.05\right)$. 
Table 1: The genes analysed in this study

\begin{tabular}{|c|c|c|c|}
\hline Official Symbol & Official Full Name & Official Symbol & Official Full Name \\
\hline Apc & adenomatosis polyposis coli & Kras & Kirsten rat sarcoma viral oncogene homolog \\
\hline Brms1 & breast cancer metastasis-suppressor 1 & Lpar6 & lysophosphatidic acid receptor 6 \\
\hline $\mathrm{Cd} 7$ & chemokine (C-C motif) ligand 7 & Mcam & melanoma cell adhesion molecule \\
\hline Cdh1 & cadherin 1 & $\mathrm{Mdm} 2$ & transformed mouse $3 \mathrm{~T} 3$ cell double minute 2 \\
\hline Cdh11 & cadherin 11 & Mmp10 & matrix metallopeptidase 10 \\
\hline $\operatorname{Cdh} 6$ & cadherin 6 & Mmp11 & matrix metallopeptidase 11 \\
\hline $\operatorname{Cdh} 8$ & cadherin 8 & Mmp13 & matrix metallopeptidase 13 \\
\hline Cdkn2a & cyclin-dependent kinase inhibitor $2 \mathrm{~A}$ & Mmp2 & matrix metallopeptidase 2 \\
\hline $\mathrm{Cdh} 4$ & $\begin{array}{l}\text { chromodomain helicase DNA } \\
\text { binding protein } 4\end{array}$ & Mmp3 & matrix metallopeptidase 3 \\
\hline Col4a2 & collagen, type IV, alpha 2 & Mmp7 & matrix metallopeptidase 7 \\
\hline Csf1 & colony stimulating factor 1 & Mmp9 & matrix metallopeptidase 9 \\
\hline Ctbp1 & C-terminal binding protein 1 & Mta1 & metastasis associated 1 \\
\hline Ctnnal & $\begin{array}{l}\text { catenin (cadherin associated } \\
\text { protein), alpha } 1\end{array}$ & Mtss1 & metastasis suppressor 1 \\
\hline Ctsk & cathepsin $\mathrm{K}$ & Myc & myelocytomatosis oncogene \\
\hline Ctsl & cathepsin L & MycI & $\begin{array}{l}\text { v-myc avian myelocytomatosis viral } \\
\text { oncogene lung carcinoma derived }\end{array}$ \\
\hline $\mathrm{Cxcl12}$ & chemokine (C-X-C motif) ligand 12 & Nf2 & neurofibromin 2 \\
\hline Cxcr2 & chemokine (C-X-C motif) receptor 2 & Nme1 & NME/NM23 nucleoside diphosphate kinase 1 \\
\hline Cxcr4 & chemokine (C-X-C motif) receptor 4 & Nme2 & NME/NM23 nucleoside diphosphate kinase 2 \\
\hline Denr & density-regulated protein & Nme4 & NME/NM23 nucleoside diphosphate kinase 4 \\
\hline Elane & elastase & $\mathrm{Nr} 4 \mathrm{a} 3$ & nuclear receptor subfamily 4 , group A, member 3 \\
\hline Ephb2 & Eph receptor B2 & Plaur & plasminogen activator, urokinase receptor \\
\hline Etv4 & ets variant 4 & Pnn & pinin \\
\hline Ewsr1 & Ewing sarcoma breakpoint region 1 & Pten & phosphatase and tensin homolog \\
\hline Fat1 & FAT atypical cadherin 1 & $\mathrm{Rb} 1$ & RB transcriptional corepressor 1 \\
\hline Fgfr4 & fibroblast growth factor receptor 4 & Rorb & RAR-related orphan receptor beta \\
\hline Flt4 & FMS-like tyrosine kinase 4 & Rpsa & ribosomal protein SA \\
\hline Fn1 & fibronectin 1 & Set & SET nuclear oncogene \\
\hline Fxyd5 & $\begin{array}{l}\text { FXYD domain-containing ion } \\
\text { transport regulator } 5\end{array}$ & Smad2 & SMAD family member 2 \\
\hline Gpnmb & glycoprotein (transmembrane) nmb & Smad4 & SMAD family member 4 \\
\hline Hgf & hepatocyte growth factor & Src & Rous sarcoma oncogene \\
\hline Hpse & heparanase & Sstr2 & somatostatin receptor 2 \\
\hline Hras & Harvey rat sarcoma virus oncogene & Syk & spleen tyrosine kinase \\
\hline Htatip2 & HIV-1 Tat interactive protein 2 & Tcf 20 & transcription factor 20 \\
\hline Igf1 & insulin-like growth factor 1 & Tgfb1 & transforming growth factor, beta 1 \\
\hline II18 & interleukin 18 & Timp2 & tissue inhibitor of metalloproteinase 2 \\
\hline IIIb & interleukin 1 beta & Timp3 & tissue inhibitor of metalloproteinase 3 \\
\hline Itga7 & integrin alpha 7 & Timp4 & tissue inhibitor of metalloproteinase 4 \\
\hline Itgb3 & integrin beta 3 & Tnfsf10 & $\begin{array}{l}\text { tumor necrosis factor (ligand) superfamily, } \\
\text { member } 10\end{array}$ \\
\hline Kiss 1 & KiSS-1 metastasis-suppressor & Trp53 & transformation related protein 53 \\
\hline \multirow[t]{2}{*}{ Kiss1r } & KISS1 receptor & Tshr & thyroid stimulating hormone receptor \\
\hline & & Vegfa & vascular endothelial growth factor A \\
\hline
\end{tabular}


A

tongue

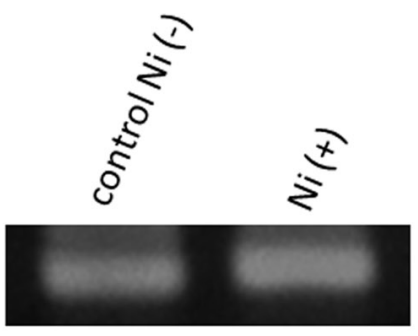

lymph node

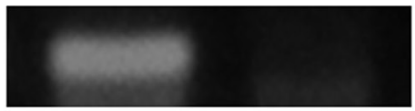

B

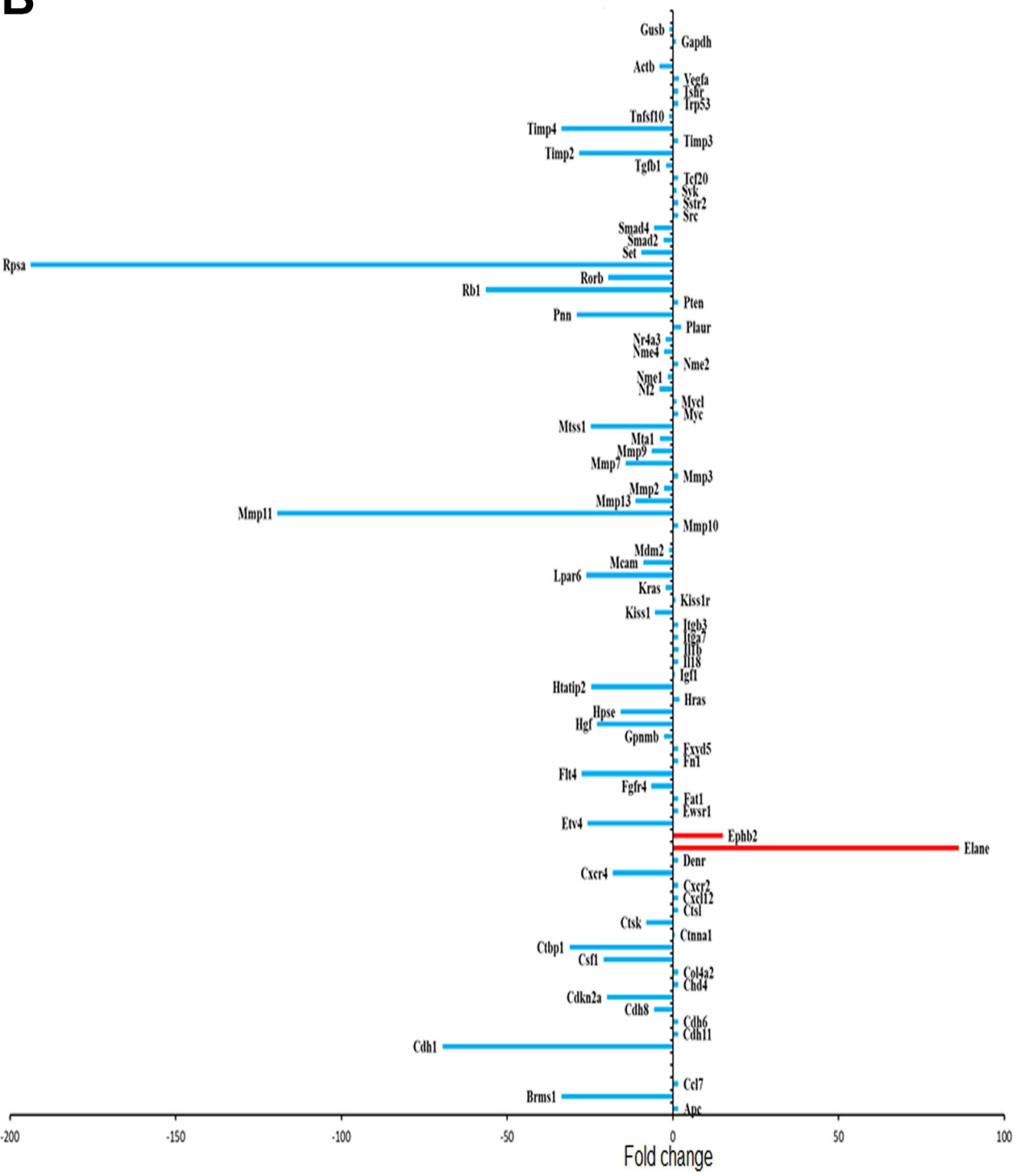

Figure 5: Anti-metastatic effect of $\mathbf{N i}^{2+}$. (A) After 2 weeks of breeding with $1 \mathrm{mM} \mathrm{NiCl}$-containing water or regular water, primary tongue regions (upper panel) and lymph nodes (lower panel) were excised from 6 mice of each group. Genomic DNA was purified and subjected to PCR for $\beta$-globin gene. The representative of 6 separate experiments were shown. (B) RNA was purified from the tongue tissues obtained from nude mice fed with $(n=3)$ or without $\mathrm{NiCl}_{2}$-containing water $(n=3)$. PCR array was performed with $\mathrm{RT}^{2}$ Profiler PCR Array kit (QIAGEN) to examine the expression levels of the cancer metastatic genes. Expression levels of each gene relative to those in the $\mathrm{Ni}^{2+}$ non-fed control mice are shown. The representative of 2 different experiments were shown. 
confirmed by real-time PCR. The promoters of all these MMPs contain the NF- $\kappa \mathrm{B}$ binding site; therefore, $\mathrm{Ni}^{2+}$ ions were expected to bind to these sites and inhibit the expression of these proteinases [18]. Consistent with our expectation, significant reductions in MMP expression were observed. Nevertheless, small amount of the mRNA expression was remained. MMP promoter conformation is classified into three different categories based on the existence of the TATA box and activator protein-1 (AP1) sites [19]. AP-1 is a chief cis-acting element for the induction of MMPs, and the importance of both AP-1 and NF- $\kappa \mathrm{B}$ on 12-O-tetradecanoylphorbol-13-acetate (TPA)induced MMP9 expression has been reported previously [20]. Incomplete reduction of MMPs by $\mathrm{Ni}^{2+}$ ions might be attributed to the contribution of AP-1 and/or other transcription factors in OSCCs. In the cases of MMP2 and 14 , however, the AP-1 sites are absent. Thus, $\mathrm{Ni}^{2+}$ ions -mediated MMP reduction mechanisms should be clarified in more detail.

Based on the above results, we presumed that the $\mathrm{Ni}^{2+}$ ions could exert inhibitory effects in vivo. A 2-week administration of $\mathrm{NiCl}_{2}$-containing water did not show any histological abnormalities in mouse organs (data not shown). This observation was consistent with a previously published report [21]. Although highly carcinogenic, $\mathrm{Ni}^{2+}$ ions are a weak mutagen with no direct contributions to the mutation process $[22,23]$. MMP9 expression in implanted cancer cells has been examined by immunostaining. Surprisingly, MMP9 levels had decreased significantly in the $1 \mathrm{mM} \mathrm{NiCl}_{2}$-fed mice. In accordance with these results, significant reduction in the formation of metastatic lesions in regional lymph node were noted in the $1 \mathrm{mM} \mathrm{NiCl}_{2}$-fed mice in the present study. $\mathrm{Ni}^{2+}$ ions were found to bind directly to the NF- $\mathrm{NB}$ p50 subunit [8]; hence, in order for them to have an effect the ions must be incorporated into the cytoplasm. This can be done by three different methods: 1) diffusion across the cell membrane, 2) transport via calcium and ion channels, and 3) phagocytosis [22, 23]. Transport of $\mathrm{Ni}^{2+}$ ions has been inhibited by intestinal Caco2 cells in the presence of $\mathrm{Fe}^{2+}$ [24]. Further investigations revealed the contribution of the proton-coupled divalent cation transporter (DCT1 and Nramp2) during this process $[25,26]$, which has a broad substrate range. $\mathrm{Ni}^{2+}$ ions are intrinsic nutrients for some bacteria, and must be taken up via a nickel transporter localized in the periplasm, which is composed of five different genes (Nik A to E), and allow for the active transport of the ions into the cytoplasm [27-29]. To gain insights into phagocytic $\mathrm{Ni}^{2+}$ ions-incorporation, HSC3 cells were pre-incubated with phagocytosis inhibitor, monodansylcadaverine and rottelerin. The effects of these inhibitors were assessed by measuring IL-8 concentrations in the culture supernatants; however, neither of them exerted any inhibitory effect (Supplementary Figure 1). An alternative mechanism should be receptor-mediated internalization. $\mathrm{Ni}^{2+}$ ions are chief drivers of contact allergy. Nonetheless, the specific interacting receptor has not been identified so far. Recently, human toll-like receptor 4 (TLR4) was demonstrated to interact with $\mathrm{Ni}^{2+}$ ions through histidine residues in the extracellular region [30]. The routes of $\mathrm{Ni}^{2+}$ ions-incorporation need to be examined in future.

In our previous study, $\mathrm{Ni}^{2+}$ ions were shown to bind directly to a histidine cluster in the Rel-homology domain (RHD) of the NF- $\kappa$ B p50 subunit [8]. RHD encompasses the nuclear localization sequence (NLS) in its most C-terminal region [31]. The NLS is recognized by its receptor importin $\alpha$ and this interaction is indispensable for the nuclear translocation of the NF- $\kappa \mathrm{B}$ complex [32]. Moreover, importin $\alpha$ was originally identified by its $\mathrm{Ni}^{2+}$ ion binding ability [33]. It might be speculated that the binding of $\mathrm{Ni}^{2+}$ ions to $\mathrm{p} 50$ or importin $\alpha$ might modify its three-dimensional structure and prevent the recognition between importin $\alpha$ and p50 NLS.

Histological examinations revealed the formation of a necrotic area within the cancer mass in $\mathrm{NiCl}_{2}$-fed mice. The formation of this structure, which presented as a hypertranslucent area in CT images, might be due to the lack of angiogenic factors such as IL-8 and VEGF [34]. In HSC3 cells, IL-8 is constitutively produced under the control of NF- $\kappa \mathrm{B}$ [8]. $\mathrm{Ni}^{2+}$ ions administration might reduce the production of angiogenic factors through inactivation of $\mathrm{NF}-\kappa \mathrm{B}$. Consistent with this hypothesis, in the $\mathrm{Ni}^{2+}$ ions-fed group, decreased expression of IL-8 and VEGF mRNA was observed. Moreover, PCR array analysis, which focused on the genes related to cancer metastasis, confirmed the reduced expression of several genes. Only Elane and Ephb2 genes were upregulated by $\mathrm{Ni}^{2+}$ ions, the biological significance of which should be clarified in another study.

Metastatic activity was compared by detecting the $\beta$-globin gene. Although equivalent expressions were detected in the primary tongue region, $\beta$-globin gene was not detected in the regional lymph node in the $\mathrm{Ni}^{2+}$ ionsfed group. It has been reported that nickel compounds induce apoptosis in various cells [35-39]. For instance, in an attempt to elucidate the mechanisms underlying the anti-apoptotic effect of $\mathrm{NiCl}_{2}$, Yang et al. treated $\mathrm{NiCl}_{2}$ transformed bronchial epithelial cells with $1.5 \mathrm{mM} \mathrm{NiCl}_{2}$ to induce apoptosis [39]. They observed a substantial degree of apoptosis following $\mathrm{NiCl}_{2}$ treatment, which was dependent on the expression levels of anti-apoptotic gene such as Bcl2 and Bcl-xL [39]. However, in this report, transformed cells were established by treating the cells with lower concentrations of $\mathrm{NiCl}_{2}$ [39]. These data are consistent with our observations in terms of the $\mathrm{NiCl}_{2}$ concentration used during the experiments ( $\mathrm{mM}$ order of $\mathrm{NiCl}_{2}$ was used in both studies). The concentration of $\mathrm{NiCl}_{2}$ might be an important factor that influences the fate of the cell.

In conclusion, the present study illustrates the inhibitory effect of $\mathrm{Ni}^{2+}$ ions on growth in orthotopically implanted cancer cells. Further investigations are required to understand the fundamental mechanisms involved in this process. However, $\mathrm{NiCl}_{2}$ might be prove to a promising candidate for cancer therapeutics. 
Table 2: The primers used in this study

\begin{tabular}{|c|c|c|c|}
\hline Primer & & Sequence & \\
\hline \multirow[t]{2}{*}{ MMP9 } & Forward & 5'-GGG ACG CAG ACA TCG TCA TC-3' & \multirow{8}{*}{ Real-time PCR } \\
\hline & Reverse & 5'-TCG TCA TCG TCG AAA TGG GC-3' & \\
\hline \multirow[t]{2}{*}{$\beta$-actin } & Forward & 5'-GGA GCA AGT ATC TTG ATC TTC-3' & \\
\hline & Reverse & 5'-CCT TCC TGC GCA TGG AGT CCT G-3' & \\
\hline \multirow[t]{2}{*}{ IL-8 } & Forward & 5'-CCA GCC ATC AGC CAT GAG GGT-3' & \\
\hline & Reverse & 5'-GGA GCC CTT TCT GAA TCC GCA-3' & \\
\hline \multirow[t]{2}{*}{ VEGF } & Forward & 5'-GCA CCC ATG GCA GAA GG-3' & \\
\hline & Reverse & 5'-CTC GAT TGG ATG GCA GTA GCT-3' & \\
\hline \multirow[t]{2}{*}{ MMP9 } & Forward & 5'-GTG GAA TTC CCC AGA CTT GCC TA-3' & \multirow{2}{*}{ Luciferase assay } \\
\hline & Reverse & 5'-GGT GAG GGC AGA GGT GTC TGA-3' & \\
\hline GH20 & Forward & 5'-GAA GAG CCA AGG ACA GGT AC-3' & \multirow{4}{*}{ nested-PCR } \\
\hline $\mathrm{GH} 21$ & Reverse & 5' GGA AAA TAG ACC AAT AGG CGA-3' & \\
\hline KM29 & Forward & 5'-GGT TGG CCA ATC TAC TCC CAG G-3' & \\
\hline KM38 & Reverse & 5'-TGG TCT CCT TAA ACC TGT CTT G-3' & \\
\hline
\end{tabular}

\section{MATERIALS AND METHODS}

\section{Reagents}

Nickel chloride $\left(\mathrm{NiCl}_{2}\right)$ was purchased from Sigma (St. Louis, MO). Antibodies (Ab) against human MMP9 and glyceraldehyde-3-phosphate dehydrogenase (GAPDH) were purchased from Santa Cruz (Santa Cruz, CA). Horseradish peroxidase (HRP)-conjugated goat antirabbit and anti-mouse IgG $(\mathrm{H}+\mathrm{L})$ Abs were purchased from Jackson ImmunoResearch (West Grove, PA, USA).

\section{Cell culture and $\mathrm{Ni}^{2+}$ ions stimulation}

The human OSCC cell lines (HSC3 and its subclone HSC3-M3 and HSC2) and human skin-derived squamous cell carcinoma cell lines (HSC1 and HSC5) [40] were obtained from Health Science Research Resources Bank (Osaka, Japan). $\mathrm{HSC} 3, \mathrm{HSC} 3-\mathrm{M} 3$ and $\mathrm{HSC} 2$ were maintained in RPMI1640. HSC1 and HSC5 were maintained in Dulbecco's minimum essential medium (DMEM) and Iscove's Modified Dulbecco's Medium (IMDM), respectively. Each medium was supplemented with $10 \%$ FCS, $50 \mu \mathrm{g} / \mathrm{ml}$ streptomycin and $50 \mathrm{U} / \mathrm{ml}$ penicillin $(10 \%$ FCS-RPMI, 10\% FCS-DMEM and 10\% FCS-IMDM). To test $\mathrm{Ni}^{2+}$ ion stimulation, $2 \times 10^{5}$ cells were plated in a $24-$ well dish on the day before the experiment. The cells were washed twice with $10 \%$ FCS-RPMI and further cultured in the presence or absence of $1 \mathrm{mM} \mathrm{Ni}^{2+}$ ions.

\section{Real time-polymerase chain reaction (PCR) and PCR array analysis}

Total RNA was purified using RNeasy mini kit (QIAGEN, Tokyo, Japan). cDNA was synthesized with
Superscript III reverse transcriptase (Invitrogen, San Diego, CA) and subjected to real-time PCR [41]. Real-time PCR was performed using LightCycler nano (Roche, Tokyo, Japan) with SYBR green (TaKaRa, Tokyo, Japan). The primers used in this study are listed in Table 2 . RT ${ }^{2}$ Profiler PCR Array kit (QIAGEN) was used for PCR array analysis.

\section{Immunoprecipitation (IP) and Western blotting}

HSC 3 cells were stimulated with or without $1 \mathrm{mM}$ $\mathrm{Ni}^{2+}$ ions for $24 \mathrm{~h}$. After stimulation, the cells were washed twice with ice cold PBS and lysed with $500 \mu \mathrm{l}$ of cell lysis buffer $(50 \mathrm{mM}$ Tris- $\mathrm{HCl}, \mathrm{pH} 7.5,150 \mathrm{mM} \mathrm{NaCl}$ and $0.5 \%$ TritonX-100). After centrifugation, the samples were transferred to new tubes and rotated with $1 \mu \mathrm{l}$ of rabbit anti-human MMP9 $\mathrm{Ab}$ for $24 \mathrm{~h}$ at $4^{\circ} \mathrm{C}$. Protein G-sepharose (10 $\mu \mathrm{l}$, GE Healthcare, USA) was added to the samples, which were then rotated for another $2 \mathrm{~h}$. At the end of incubation, the samples were washed with ice cold PBS by centrifugation, loaded on to $10 \%$ SDS-PAGE and subjected to Western blotting as described previously [41]. The primary Ab against MMP9 was diluted to $\times 1,000$ with $1 \%$ BSA-PBST $(0.1 \%$ tween-20/PBS). The secondary HRP-goat anti-mouse $\operatorname{IgG}(\mathrm{H}+\mathrm{L})$ was diluted to $\times 10,000$ with $1 \%$ BSA-PBST. The bands were detected using an ECL kit (GE Healthcare).

\section{Cloning of 5'-untranslated region (UTR) of MMP9 gene and plasmid construction}

The luciferase construct containing a $626 \mathrm{bp}$ fragment of the MMP9 gene promoter spanning from -626 to -1 ( +1 corresponds to the A of the ATG translation initiation codon) was amplified using the primers listed in Table 1. The amplified fragment was subcloned into the Hind III 
and Kpn I sites of the pGL4-basic vector (Promega, Tokyo, Japan). This reporter construct was designated as the wild type (pGL4-MMP9-wt). Using this plasmid as a template, deletion mutants lacking upper and lower NF- $\kappa \mathrm{B}$ binding sites were constructed uing the QuickChange Site-directed Mutagenesis kit (Agilent Technologies, Tokyo, Japan), and designated as $\Delta$ upper and $\Delta$ lower, respectively.

\section{Luciferase assay}

HSC 3 cells were plated in 48-well culture plates at a density of $1 \times 10^{5}$ cells/well. The cells were washed twice with OPTI-MEM and transfected with $1 \mu \mathrm{g}$ of reporter plasmids (pGL4-MMP9-wt, $\Delta$ upper or $\Delta$ lower) using the Lipofectamin transfection method (Invitrogen, Tokyo, Japan). After $5 \mathrm{~h}$ of transfection, the cells were washed with 10\% FCS-RPMI and further cultured for $18 \mathrm{~h}$. Then, the cells were washed and either left unstimulated or stimulated with $1 \mathrm{mM} \mathrm{Ni}^{2+}$ ions for 12 and $24 \mathrm{~h}$. After stimulation, the cells were lysed with $1 \times$ passive lysis buffer (Promega, Tokyo, Japan) and cell lysates were collected. Transfection efficiency was normalized to renilla luciferase activity by co-transfection with the $\mathrm{pRL} /$ CMV vector (Promega). Both firefly and renilla luciferase activities were determined using the Dual-Luciferase Reporter Assay System (Promega). Luminescence was measured on a Lumat LB9507 luminometer (Berthold, Bad Wildbad, Germany).

\section{Orthotopic implantation and immunohistochemistry}

HSC3-M3 cells $\left(5 \times 10^{5} / 50 \mu \mathrm{PBS}\right)$ were injected into the right edge of the tongue of male nude mice. (CLEA, Tokyo, Japan). Experimental protocols were approved by the Nihon University School of Dentistry Animal Ethical Committee and performed according to legal requirements (AP14D030). Tumor formation was monitored every week. After cancer mass formation, the mice were fed with regular drinking water or $1 \mathrm{mM}$ $\mathrm{NiCl}_{2}$-supplemented drinking water for 7 or 14 days. The mice were sacrificed by $\mathrm{CO}_{2}$ inhalation and fixed by perfusion with formalin. The cancer tissue was excised and embedded in paraffin. Four-micrometer-thick sections were prepared, deparaffinised in xylene and rehydrated with $100 \%$ ethanol. Endogenous peroxidase activity was inactivated with $0.3 \%$ hydrogen peroxide in methanol for $20 \mathrm{~min}$ at room temperature (RT). The sections were boiled in $10 \mathrm{mM}$ citrate buffer ( $\mathrm{pH} \mathrm{6.0)}$ ) for $20 \mathrm{~min}$ and cooled down. To block non-specific binding, the sections were incubated with $1 \%$ BSA-PBS at RT for $1 \mathrm{~h}$. The blocking solution was removed, and the first $\mathrm{Ab}$ was applied following which, the samples were incubated at RT for $1 \mathrm{~h}$. Negative control studies were incubated with $1 \%$ BSA-PBS instead of the first Ab. The sections were then incubated with HRP-conjugated goat anti-rabbit
IgG (diluted to $1 / 500$ ) for $1 \mathrm{~h}$, at RT. After washing, the sections were developed with freshly prepared diaminobenzidine (DAB) chromogen solution (Sigma, Tokyo, Japan) for $7 \mathrm{~min}$, counterstained with haematoxylin for $30 \mathrm{~s}$, dehydrated in a series of ethanol dilutions, cleared in xylene, and mounted on glass coverslips. The images were viewed and photographed using a light microscope (Olympus, Tokyo, Japan). For computerized tomography (CT) analysis, a contrast agent was injected to the tail vein and $\mathrm{CT}$ images of the primary regions were obtained by Cosmo Scan (Rigaku, Tokyo, Japan).

\section{Tissue handling}

HSC3-M3 cells $\left(5 \times 10^{5} / 35 \mu \mathrm{l}\right.$ PBS $)$ were injected into the right edge of the tongue of male nude mice. Primary tumor mass and cervical lymph nodes were removed from $\mathrm{NiCl}_{2}$-fed and control mice 3 weeks later. The tissues were divided into two parts, one for paraffinembedded sectioning and H\&E staining, and the other for genomic DNA and total RNA extraction. Metastatic frequency was evaluated by detecting human $\beta$-globin gene according to the protocol described previously [42]. For real-time PCR and PCR array analysis, total RNA was extracted from the excised tongue tissues using the RNeasy mini kit (QIAGEN, Tokyo, Japan). For IPWestern blotting, the tumor mass were excised, minced and lysed with the cell lysis buffer. The IP-Western was performed as described above.

\section{Statistical analysis}

Results are presented as mean \pm SD from at least three independent experiments. Statistical differences were assessed using Student's $t$-test, Welch's test or Steel-Dwass test. A $P$ value of $<0.05$ was considered as significant.

\section{Author contributions}

$\mathrm{HO}$ and TS contributed equally to this work. YA and MA conceived and designed the study. HO, TS, HS, $\mathrm{SS}$ and $\mathrm{KU}$ performed the experiments and analyses. MA wrote the main manuscript and prepared all tables and figures. All authors reviewed the manuscript.

\section{ACKNOWLEDGMENTS}

We thank to Dr. Yasuko Kato for the technical assistance regarding the a contrast agent injection.

\section{CONFLICTS OF INTEREST}

Authors don't declare any conflicts of interest. 


\section{FUNDING}

This study was supported in part by research grants from Sato Fund from the Nihon University School of Dentistry and a grant from the Dental Research Center, Nihon University School of Dentistry, a Nihon University multidisciplinary research grant and Individual Research Grant and MEXT-Supported Program for the Strategic Research Foundation at Private Universities 2013-2017. Grant-in-Aid for Scientific Research (C) (MEXT).

\section{REFERENCES}

1. Molinolo AA, Amornphimoltham P, Squarize $\mathrm{CH}$, Castilho RM, Patel V, Gutkind JS. Dysregulated molecular networks in head and neck carcinogenesis. Oral Oncology. 2009; 45:324-334.

2. Karin M. Nuclear factor- $\kappa B$ in cancer development and progression. Nature. 2006; 441:431-436.

3. Hayden MS, Ghosh S. Shared principles in NF- $\mathrm{kB}$ signaling. Cell. 2008; 132:344-362.

4. Ondrey FG, Dong G, Sunwoo J, Chen Z, Wolf JS, Crowl-Bancroft CV, Mukaida N, Van Waes C. Constitutive activation of transcription factors NF$\kappa \mathrm{B}, \mathrm{AP}-1$, and NF-IL6 in human head and neck squamous cell carcinoma cell lines that express proinflammatory and pro-angiogenic cytokines. Mol Carcinog. 1999; 26:119-129.

5. Bindhu OS, Ramadas K, Sebastian P, Pillai MR. High expression levels of nuclear factor kappa B and gelatinases in the tumorigenesis of oral squamous cell carcinoma. Head Neck. 2006; 28:916-925.

6. Sawhney M, Rohatgi N, Kaur J, Shishodia S, Sethi G, Gupta SD, Deo SV, Shukla NK, Aggarwal BB, Ralhan R. Expression of NF- $\mathrm{kB}$ parallels COX-2 expression in oral precancer and cancer: association with smokeless tobacco. Int J Cancer. 2007; 120:2545-2556.

7. Mishra A, Bharti AC, Varghese P, Saluja D, Das BC. Differential expression and activation of NF- $\mathrm{KB}$ family proteins during oral carcinogenesis: Role of high risk human papillomavirus infection. Int $\mathrm{J}$ Cancer. 2006; 119:2840-2850.

8. Shionome T, Endo S, Omagari D, Asano M, Toyoma H, Ishigami T, Komiyama K. Nickel inhibits nuclear factor kappa B activity in human oral squamous cell carcinoma. PLoS One. 2013; 8:e68257.

9. Kessenbrock K, Plaks V, Werb Z. Matrix metalloproteinases: regulators of the tumor microenvironment. Cell. 2010; 141:52-67.

10. Page-McCaw A, Ewald AJ, Werb Z. Matrix metalloproteinases and the regulation of tissue remodelling. Nat Rev Mol Cell Biol. 2007; 8:221-233.

11. Roy R, Yang J, Moses MA. Matrix metalloproteinases as novel biomarkers and potential therapeutic targets in human cancer. J Clin Oncol. 2009; 27:5287-5297.

12. Collier IE, Wilhelm SM, Eisen AZ, Marmer BL, Grant GA, Seltzer JL, Kronberger A, He CS, Bauer EA, Goldberg GI. H-ras oncogene-transformed human bronchial epithelial cells (TBE-1) secrete a single metalloprotease capable of degrading basement membrane collagen. J Biol Chem. 1988; 263:6579-6587.

13. Condeelis J, Pollard JW. Macrophages: obligate partners for tumor cell migration, invasion, and metastasis. Cell. 2006; 124:263-266.

14. Seiki M. Membrane-type 1 matrix metalloproteinase a key enzyme for tumor invasion. Cancer Lett. 2003; 194:1-11.

15. Mohtasham N, Babakoohi S, Shiva A, Shadman A, Kamyab-Hesari K, Shakeri MT, Sharifi-Sistani N. Immunohistochemical study of p53, Ki-67, MMP-2 and MMP-9 expression at invasive front of squamous cell and verrucous carcinoma in oral cavity. Pathol Res Pract. 2013; 209:110-114.

16. Chakraborti S, Mandal M, Das S, Mandal A, Chakraborti T. Regulation of matrix metalloproteinases: an overview. Mol Cell Biochem. 2003; 253:269-285.

17. Werb Z. ECM and cell surface proteolysis: regulating cellular ecology. Cell. 1997; 91:439-442.

18. Vincenti MP, Brinckerhoff CE. Signal transduction and cell-type specific regulation of matrix metalloproteinase gene expression: can MMPs be good for you? J Cell Physiol. 2007; 213:355-364.

19. Clark IM, Swingler TE, Sampieri CL, Edwards DR. The regulation of matrix metalloproteinases and their inhibitors. Int J Biochem Cell Biol. 2008; 40:1362-1378.

20. Chen HW, Chao CY, Lin LL, Lu CY, Liu KL, Lii CK, $\mathrm{Li}$ CC. Inhibition of matrix metalloproteinase-9 expression by docosahexaenoic acid mediated by heme oxygenase 1 in 12-O-tetradecanoylphorbol-13acetate-induced MCF-7 human breast cancer cells. Arch Toxicol. 2013; 87:857-869.

21. Sunderman FW Jr, Maenza RM, Alpass PR, Mitchell JM, Damjanov I, Goldblatt PJ. Carcinogenicity of nickel subsulfide in Fischer rats and Syrian hamsters after administration by various routes. Adv Exp Med Biol. 1977; 91:57-67.

22. Costa M, Davidson TL, Chen H, Ke Q, Zhang P, Yan Y, Huang C, Kluz T. Nickel carcinogenesis: epigenetics and hypoxia signaling. Mutat Res. 2005; 592:79-88.

23. Kasprzak KS, Sunderman FW Jr, Salnikow K. Nickel carcinogenesis. Mutat Res. 2003; 533:67-97.

24. Tallkvist J, Tjalve H. Transport of nickel across monolayers of human intestinal Caco-2 cells. Toxicol Appl Pharmacol. 1998; 151:117-122.

25. Gunshin H, Mackenzie B, Berger UV, Gunshin Y, Romero MF, Boron WF, Nussberger S, Gollan JL, 
Hediger MA. Cloning and characterization of a mammalian proton-coupled metal-ion transporter. Nature. 1997; 388:482-488.

26. Knopfel M, Schulthess G, Funk F, Hauser H. Characterization of an integral protein of the brush border membrane mediating the transport of divalent metal ions. Biophys J. 2000; 79:874-884.

27. Navarro C, Wu LF, Mandrand-Berthelot MA. The nik operon of Escherichia coli encodes a periplasmic binding-protein-dependent transport system for nickel. Mol Microbiol. 1993; 9:1181-1191.

28. Schulz GE. Bacterial porins: structure and function. Curr Opin Cell Biol. 1993; 5:701-707.

29. Rowe JL, Starnes GL, Chivers PT. Complex transcriptional control links NikABCDE-dependent nickel transport with hydrogenase expression in Escherichia coli. J Bacteriol. 2005; 187:6317-6323.

30. Schmidt M, Raghavan B, Müller V, Vogl T, Fejer G, Tchaptchet S, Keck S, Kalis C, Niselsen PJ, Galanos C, Roth J, Skerra A, Martin SF, et al. Crucial role for human Toll-like receptor 4 in the development of contact allergy to nickel. Nat Immunol. 2010; 11:814-819.

31. Bonizzi G, Karin M. The two NF- $\kappa$ B activation pathways and their role in innate and adaptive immunity. Trends Immunol. 2004; 25:280-288.

32. Fagerlund R, Kinnunen L, Köhler M, Julkunen I, Melén K. NF- $\kappa \mathrm{B}$ is transported into the nucleus by Importin $\alpha 3$ and Importin $\alpha 4$. J Biol Chem. 2005; 280:15942-15951.

33. Görlich D, Prehn S, Laskey RA, Hartmann E. Isolation of a protein that is essential for the first step of nuclear protein import. Cell. 1994; 79:767-778.

34. Waugh DJ, Wilson C. The interleukin-8 pathway in cancer. Clin Cancer Res. 2008; 14:6735-6741.

35. Kim K, Lee SH, Seo YR, Perkins SN, Kasprzak KS. Nickel(II)-induced apoptosis in murine $\mathrm{T}$ cell hybridoma cells is associated with increased fas ligand expression. Toxicol Appl Pharmacol. 2002; 185:41-47.
36. Li Q, Suen TC, Sun H, Arita A, Costa M. Nickel compounds induce apoptosis in human bronchial epithelial Beas-2B cells by activation of c-Myc through ERK pathway. Toxicol Appl Pharmacol. 2009; 235:191-198.

37. Ding J, He G, Gong W, Wen W, Sun W, Ning B, Huang S, Wu K, Huang C, Wu M, Xie W, Wang H. Effects of nickel on cyclin expression, cell cycle progression and cell proliferation in human pulmonary cells. Cancer Epidemiol Biomarkers Prev. 2009; 18:17201729.

38. Zhao J, Bowman L, Zhang X, Shi X, Jiang B, Castranova V, Ding M. Metallic nickel nano- and fine particles induce JB6 cell apoptosis through a caspase-8/AIF mediated cytochrome c-independent pathway. J Nanobiotechnology. 2009; 7:2.

39. Yang YX, Li XL, Wang L, Han SY, Zhang YR, Pratheeshkumar P, Wang X, Lu J, Yin YQ, Sun LJ, Budhraja A, Hitron AJ, Ding SZ. Anti-apoptotic proteins and catalase-dependent apoptosis resistance in nickel chloride-transformed human lung epithelial cells. Int J Oncol. 2013; 43:936-946.

40. Momose F, Araida T, Negishi A, Ichijo H, Shioda S, Sasaki S. Variant sublines with different metastatic potentials selected in nude mice from human oral squamous cell carcinomas. J Oral Pathol Med. 1989; 18:391-395.

41. Omagari D, Mikami Y, Suguro H, Sunagawa K, Asano M, Sanuki E, Moro I, Komiyama K. Poly $\mathrm{I}$ :C-induced expression of intercellular adhesion molecule-1 in intestinal epithelial cells. Clin Exp Immunol. 2009; 156:294-302.

42. Shigeta T, Umeda M, Komatsubara H, Komori T. Lymph node and pulmonary metastases after transplantation of oral squamous cell carcinoma cell line (HSC-3) into the subcutaneous tissue of nude mouse: detection of metastases by genetic methods using beta-globin and mutant p53 genes. Oral Surg Oral Med Oral Pathol Oral Radiol Endod. 2008; 105:486-490. 